\title{
The Research of E- Learning Environment Design Based on The Theory of Multiple Intelligences
}

\author{
FENG Yi-dong ${ }^{\mathrm{a}}$, GUI Zhan-ji ${ }^{\mathrm{b}}$, FANG Yun-duan ${ }^{\mathrm{c}}$, WANG Xiao-xia ${ }^{\mathrm{a}, \mathrm{d}}$ \\ ${ }^{a}$ College of Information Science and Technology, Hainan Normal University, Haikou, China \\ ${ }^{b}$ Hainan Software Profession Institute, Qionghai, China \\ ${ }^{c}$ Yunnan Normal University, Kunming, China
}

\begin{abstract}
E-learning environment has incomparable advantages compared to traditional education, which could make up for traditional educational means and methods in preparing students multiple intelligence shortcomings, in line with our current educational status quo. The research on e-learning environment design based on the theory of multiple intelligence lies in both students' multiple intelligences, and enhancing network education quality, which has an important practical significance. This paper analyzes the inspiration of multi-intelligence theory as for e-learning environment design based on the multiple intelligences theory, which also proposes learning strategies for environmental design and some problems that we should pay attention to.
\end{abstract}

Index Terms: Component; multiple intelligence; e-learning environment; design strategies

(C) 2011 Published by MECS Publisher. Selection and/or peer review under responsibility of the International Conference on E-Business System and Education Technology

\section{Introduction}

Because of the unsatisfactory current online education quality, how to improve current online education quality is an urgent to study and solve. Multiple Intelligences theory has injected new momentum for the online education and provided a theoretical foundation for the online education. Therefore, under the guidance of multiintelligences theory, it has important practical significance to the research on e-learning environment in the current situation and the development of students' multiple intelligences.

\section{The inspiration FOR e-learning environment design based on Multi-Intelligences theory.}

Theory of multiple intelligences has used a whole new perspective to study human intelligence, considering every person's intelligence as pluralistic, and analyzing the characteristics of each type of intelligence and ideas

* Corresponding author.

E-mail address: ${ }^{\mathrm{a}}$ fengyidong@ @hainnu.edu.cn, ${ }^{\mathrm{b}}$ zhanjigui@ @ sohu.com, ${ }^{\mathrm{c}} 24428454 @$ qq.com, ${ }^{\mathrm{d}}$ spicehb@ hotmail.com 
of intelligent training and evaluation. This provided an important revelation to e-learning environment design. According to multiple intelligences theory, in the process of designing network learning environment, we should pay attention to the diversity of content representation, individualized e-learning resources design, diversity of evaluation on student learning, situated of the implementation of network curriculum, and should be focus on capacity-building. [1]

\section{A. Representation of the diverse teaching content}

Multi-intelligences theory emphasizes that each person's intelligence is diverse. There are at least eight kinds of intelligence, but not all intelligences are in balanced development. One or two kinds of intelligences are usually higher than other smart, and relatively well been developed. In general, each type of intelligence has a different. A number of intelligent compositions and mode of operation have their own characteristics. Therefore, each person should show his or her unique cognitive characteristics.

Therefore, in the design process of e-learning environment, the representation of teaching content should be diversified. When the same content in expressing should be show with a variety of ways, and this can mobilize the strengths of the students to overcome their weaknesses, so that the online environment is suitable for different students to learn, to maximize the learner's intellectual potential of mining to promote the development of multiple intelligences of students. Under the guidance of multi-intelligences Theory, the curriculum requires the teaching to start around the eight kinds of intelligences, and by playing different role in intelligence activities to improve the teaching effect. In this way, each student will be able to fit the characteristics of its own intelligent way, through a variety of ways to achieve mastery of a specific content.

Traditional learning environment is aimed at developing student's linguistic intelligence and mathematical logic intelligence. Teachers did not fully take the diversification of resources into account, but from their points of teachers, in accordance with reasonable idea of themselves of the teaching thinking to design the learning environment. For example, while learning the "isosceles triangle", teachers often give students some analysis of both positive and negative aspects of the definition of isosceles triangle without taking the different characteristics of the students intelligent into account, often resulting in that some students can not understand what they have learned. After course trained, students not only get one-sided development and no individuality and creativity, but also lack of practical ability and this course is not conducive to the development of students' multiple intelligences. Gardner believes that curriculum should be adjusted so as to adapt to different learning styles and strengths.

\section{B. The design of network resources should be individualized}

Theory of Multiple Intelligences emphasizes that every person has at least eight intelligence, but the ability to show is different. Because of these differences, each person's learning style and intelligent type has unique features, which mainly reflected in their respective possess different smart combination. Traditionally, we consider some students as "bad students", simply because their performances of linguistic intelligence or the mathematical logic intelligence are not good enough. We should realize that their performances on several other intelligence might be very good. In this sense, every student is the best, there is no question of the level of intelligence, and there is only the difference in types of learning intelligence issues. Therefore, network resources must be designed to highlight the individualized and personalized resources in order to adapt to each student's learning so that they can get the best of their development.

\section{Evaluation on students should be diversified}

The assessment of multiple intelligences theory is designed to discover each person's intellectual potential and characteristics, to identify and develop their intelligence and interests different from the others and help them to realize the full development of personality characteristics and to provide them with a sense of selfvalue to establish an effective means in order to promote the hearts of each person comprehensively and completely.

Traditionally, our evaluation on students has only one model or standard, evaluations are mainly confined to linguistic intelligence and mathematical logic intelligence, and evaluation has great one-sidedness and limitations. It makes part of the language or mathematical logic intelligent students who perform not well have 
lost interest in learning and self-confidence. According to the theory of multiple intelligences, various intelligences which are made of different combinations emphasize that everybody has an individual characteristics. Therefore, there is a not uniform evaluation criterion for every person. Learning environment design should find a variety of ways to evaluate the students, so that each student will be able to use the suitable styles in their smart ways of the characteristics and learning to demonstrate their knowledge and abilities. Evaluation should also be carried out in a similar practical situation of actual in order to reflect the actual problem-solving abilities and innovative capabilities. Such a diversity and appropriate evaluation will contribute to reflecting students' situations in a more fully and accurately way.

\section{The online courses should be implemented in situated}

Theory of multiple intelligences emphasis on "situational intelligence." Gardner think that the intelligences can not be seen that kind of physiological organ like stomach, also not be seen that kind of psychological attributes like emotions, favorite. A single intelligence or more intelligences have always been the interaction product of learning opportunities and physiological characteristics in certain cultural. Therefore, it should be necessary to implement the "situation" of principle in curriculum development and implementation process. We should pay attention to the learner's initiative and help them with participating in the learning situation and behave more effectively in the process of interaction with learners and environment.

\section{E. Focus on bring up the ability}

Gardner believes that intelligence include the ability to solve the problems in real life, the ability to raise and solve new problems and the ability to provide valuable creation and services right to his own culture. Clearly, the multiple intelligences theory attaches great importance to train learners to solve real problems.

Therefore, the development of the network environment needs to realize the change of learning knowledge to capacity-building, change the complex task too detailed in the past and traditional teaching methods, emphasize the ability to solve practical problems. Rote and memory education mode seriously stifle imagination and creativity of students and creativity. This can lead to waste a lot of resources of talent.

\section{The Design Strategy of E-Learning Environment Based on the Theory of Multiple Intelligences}

E-learning environment creates a good condition for diversification, individual-oriented, which is situated as well as the ability to Culture for Characterized by learning content. However, we should consider how to play the advantages of the network around the multiple intelligences in another way, and how to promote students' multiple intelligences development in some designed learning curriculum environment by using these eight kinds of intelligence. The author in reference to the U.S. David Lazear's "Multiple Intelligence Toolbox" and "Multiple intelligence technology toolbox",[2] combination of the characteristics of e-learning, analyzing the requirements of eight kinds of intelligences around of the learning environment, and providing some design strategies of the learning environment. As shown in Table 1:

TABLE 1: The DESIgn STRATEGy OF E-LEARNING ENVIRONMENTBASED ON THE THEORY OF MULTIPLE INTELLIGENCES

\begin{tabular}{|c|c|c|}
\hline $\begin{array}{l}\text { Intelligences } \\
\text { types }\end{array}$ & Require of learning environment & The design strategy of e-Learning environment \\
\hline \multirow{10}{*}{$\begin{array}{l}\text { Language } \\
\text { intelligences }\end{array}$} & \multirow{10}{*}{$\begin{array}{l}\text { Create listening, speaking, reading and } \\
\text { writing environment }\end{array}$} & 1. Providing text resources \\
\hline & & 2. Using of video on demand technology, provide video and audio \\
\hline & & 3. Providing the opportunity to dictation \\
\hline & & $\begin{array}{l}\text { 4. Through via voice chat rooms ,or OICQ debating and } \\
\text { communicating on the exchange of voice }\end{array}$ \\
\hline & & $\begin{array}{l}\text { 5. Through electronic forums, E-Mail, chat rooms, virtual classrooms, } \\
\text { OICQ, etc. to discuss and exchange Comments }\end{array}$ \\
\hline & & 6. Students tell stories to the students or lecture \\
\hline & & 7. Using network to Collect resources \\
\hline & & 8. Providing read aloud opportunities \\
\hline & & 9. Using Microsoft Word software for writing, keep a diary \\
\hline & & 10. Providing With CD-ROM, interactive books, e-books \\
\hline
\end{tabular}

National Natural Science Foundation of the Year 2009(serial number: 60963025); Hainan Province Natural Science Foundation of the Year 2008(serial number: 60895) (sponsors)

* Correspondence author 


\begin{tabular}{|c|c|c|}
\hline \multirow{10}{*}{$\begin{array}{l}\text { Mathematics } \\
\text { Logic } \\
\text { intelligences }\end{array}$} & \multirow{10}{*}{$\begin{array}{l}\text { Creating of clustering, discrimination, } \\
\text { reasoning, general, computing, problem } \\
\text { solving, hypothesis testing environment }\end{array}$} & $\begin{array}{l}\text { 1.Using concrete steps, computing processes, methods, formulas and } \\
\text { equations to solve problems }\end{array}$ \\
\hline & & $\begin{array}{l}\text { 2. Use sign language to understand and exchange, sorting the logical } \\
\text { order of things }\end{array}$ \\
\hline & & $\begin{array}{l}\text { 3. Using the database to overview and organization a variety of } \\
\text { information }\end{array}$ \\
\hline & & $\begin{array}{l}\text { 4. Use spreadsheet programs (such as Excel)to process and analysis } \\
\text { data for some subject }\end{array}$ \\
\hline & & 5. Using the data model represents the relationship between things \\
\hline & & 6. Searching and analyzing for the required network resources \\
\hline & & 7. Using the programming language programming \\
\hline & & 8. Setting out appropriate procedures to solve the problem \\
\hline & & 9. On an issue in logical deductive reasoning \\
\hline & & 10. Participating in the network math games \\
\hline \multirow{10}{*}{$\begin{array}{l}\text { Space } \\
\text { intelligences }\end{array}$} & \multirow{10}{*}{$\begin{array}{l}\text { Creating of the use of pictures, colors, } \\
\text { figurative things in the learning } \\
\text { environment }\end{array}$} & $\begin{array}{l}\text { 1. Using charts, diagrams or photographs to support the textual } \\
\text { representation }\end{array}$ \\
\hline & & $\begin{array}{l}\text { 2. Using visual outline, concept mapping, mind mapping, clustering, } \\
\text { or thinking depicted [3] records of learning content }\end{array}$ \\
\hline & & 3. Express the meaning implied in graphics or images \\
\hline & & $\begin{array}{l}\text { 4. Creating abstract graphics and patterns to reflect the relationship of } \\
\text { the different concepts, ideas or methods }\end{array}$ \\
\hline & & 5. Designing charts, concepts, ideas and methods of learning \\
\hline & & $\begin{array}{l}\text { 6. Using PhotoShop to create and edit photos, using web processing } \\
\text { to produce web pages }\end{array}$ \\
\hline & & 7. Using animation and video media to characterize learning content \\
\hline & & 8. Making full use of color to emphasize on learning content \\
\hline & & $\begin{array}{l}\text { 9. Changing the shape or the size of the graphic, and improving their } \\
\text { memory from the visual attention }\end{array}$ \\
\hline & & $\begin{array}{l}\text { 10. Using animation software, video editing software, and computer- } \\
\text { aided design software to create }\end{array}$ \\
\hline \multirow{10}{*}{$\begin{array}{l}\text { Music } \\
\text { intelligences }\end{array}$} & \multirow{10}{*}{$\begin{array}{l}\text { creating the learning environment of } \\
\text { feelings, identify and express a variety of } \\
\text { musical forms }\end{array}$} & 1. Show learning materials, provide background music \\
\hline & & $\begin{array}{l}\text { 2. Through the music to create a pleasant atmosphere, relax, inspire, } \\
\text { focus and achieve the transition }\end{array}$ \\
\hline & & 3. Play music, ask students to concept $\mathrm{f}$ the screen through the music \\
\hline & & 4. Play music so that students take the initiative to construct listening \\
\hline & & 5. Spell the word through music \\
\hline & & 6. Learn to read through music \\
\hline & & 7. use computer software to do music composition \\
\hline & & $\begin{array}{l}\text { 8. use music and sound production and editing software (such as } \\
\text { Sound Maker) to edit sound }\end{array}$ \\
\hline & & 9. Sing the song in Concert with the title of studying \\
\hline & & $\begin{array}{l}\text { 10. Provide through poetry, song lyrics to carry out learning } \\
\text { opportunities }\end{array}$ \\
\hline \multirow{4}{*}{$\begin{array}{l}\text { Physical activity } \\
\text { intelligences }\end{array}$} & \multirow{4}{*}{$\begin{array}{l}\text { create of touch, movement, limb sensory } \\
\text { learning environment }\end{array}$} & $\begin{array}{l}\text { 1. creating virtual reality environment, giving students the opportunity } \\
\text { to simulate the operation }\end{array}$ \\
\hline & & $\begin{array}{l}\text { 2. Provide a virtual laboratory for students to conduct virtual } \\
\text { experiments by computer }\end{array}$ \\
\hline & & $\begin{array}{l}\text { 3. The establishment of a variety of interactive navigation methods to } \\
\text { enable students to learn through the operation }\end{array}$ \\
\hline & & $\begin{array}{l}\text { 4. According to learning content design needs keyboard, mouse, } \\
\text { joystick or other device of the game }\end{array}$ \\
\hline
\end{tabular}




\begin{tabular}{|c|c|c|}
\hline $\begin{array}{l}\text { Interpersonal } \\
\text { intelligence }\end{array}$ & $\begin{array}{l}\text { The creation of contact with others, sharing, } \\
\text { cooperation and exchange of learning } \\
\text { environment }\end{array}$ & 1. Through the network to carry out distance learning courses \\
\hline & & 2. through OICQ , chat rooms or E-mail to communicate \\
\hline & & 3. Holding an online forum \\
\hline & & 4. The use of video conferencing systems to communicate and discuss \\
\hline & & 5. Simulating games, using software or games need to work together \\
\hline & & $\begin{array}{l}\text { 6. Organizing cooperative learning with others in the group to study a } \\
\text { topic }\end{array}$ \\
\hline & & $\begin{array}{l}\text { 7. Playing different roles in the virtual community to, express their } \\
\text { understanding, empathy training from themselves points of view or life } \\
\text { experiences. }\end{array}$ \\
\hline & & $\begin{array}{l}\text { 8. accepting others opinions or responding to others performance or } \\
\text { views }\end{array}$ \\
\hline & & 9. predict the emotion or experience of people in a particular scenario \\
\hline & & $\begin{array}{l}\text { 10. Concerned about the relationship between people and how to } \\
\text { improve this relationship }\end{array}$ \\
\hline \multirow{10}{*}{$\begin{array}{l}\text { Self-awareness } \\
\text { intelligences }\end{array}$} & \multirow{10}{*}{$\begin{array}{l}\text { The creation of self-excitation, } \\
\text { independent, self-design, self-reflective } \\
\text { learning environment }\end{array}$} & 1. Students choose learning contents and self-paced \\
\hline & & 2. enable students to learn independently \\
\hline & & 3. help students set goals and provide feedback \\
\hline & & 4. Using a variety of scales for detect themselves \\
\hline & & $\begin{array}{l}\text { 5. The use of blog which enable students to learn to write diaries, } \\
\text { records, or reflective thinking diary }\end{array}$ \\
\hline & & $\begin{array}{l}\text { 6. Provide only one person to do or to encourage independent learning } \\
\text { computer games or programs }\end{array}$ \\
\hline & & 7. enable students to describe their own thought processes \\
\hline & & $\begin{array}{l}\text { 8. provide an opportunity to students with a particular subject to } \\
\text { express personal feelings and ideas }\end{array}$ \\
\hline & & $\begin{array}{l}\text { 9. ask students to use different ways of thinking to solve different } \\
\text { problems }\end{array}$ \\
\hline & & $\begin{array}{l}\text { 10. provide material about the personal reality life for students to } \\
\text { consider and choose }\end{array}$ \\
\hline \multirow{10}{*}{$\begin{array}{l}\text { Nature } \\
\text { Observation } \\
\text { intelligences }\end{array}$} & \multirow{10}{*}{$\begin{array}{l}\text { The creation of learning environment about } \\
\text { understanding of nature, and exploring the } \\
\text { natural }\end{array}$} & $\begin{array}{l}\text { 1. Provide the image of a real response to the natural environment for } \\
\text { students }\end{array}$ \\
\hline & & $\begin{array}{l}\text { 2. Provide students with video information of a real response to the } \\
\text { operation of natural }\end{array}$ \\
\hline & & 3. Provide the natural world, weather, animals, sounds, etc \\
\hline & & $\begin{array}{l}\text { 4. The use of multimedia information simulated such as natural } \\
\text { environment, animal behavior, weather conditions, geographical } \\
\text { features }\end{array}$ \\
\hline & & $\begin{array}{l}\text { 5. The use of virtual technology virtual field nature study (such as the } \\
\text { surface of the moon, etc.) }\end{array}$ \\
\hline & & $\begin{array}{l}\text { 6. Using web search to research or to learn more about natural } \\
\text { phenomena }\end{array}$ \\
\hline & & $\begin{array}{l}\text { 7. Understand the natural phenomena of the data organization, } \\
\text { mapping or through a computer program for analysis }\end{array}$ \\
\hline & & 8. Visit Online Zoo and Botanical Gardens \\
\hline & & 9. Students through the computer simulation of nature paintings \\
\hline & & $\begin{array}{l}\text { 10. The full network of abundant resources provide students with a } \\
\text { variety of natural landscapes to explore the natural opportunities. Such } \\
\text { as conducting "Man and Nature" as its theme Learning Webquest }\end{array}$ \\
\hline
\end{tabular}




\section{The Problem Should Pay Attention to in the Design of Learning Environments}

The table provides a number of commonly used strategies for the design of the network learning environment. In the process of environmental design, we should pay more attention to promoting the development of multiple intelligences in a diverse way. However, this does not mean to copy the above strategies in the design. We provided strategy which is a reference for the design of learning environments. So we should pay attention to the following questions in this process:

\section{F. Because of different subjects nature, the choices of strategies are also different}

The main training objectives for each subject were quite different, and the provision of learning resources should also be different. For example: the main objective of mathematics is to develop students mathematical logic intelligence; the main objective of English and the language is to develop the language intelligences of students; the main objective of art is to train students in spatial intelligence and kinesthetic intelligence; the main objective of sport is to develop students kinesthetic intelligence, etc. Thus, in the process of design, we should select an appropriate corresponding strategy based on the nature of the different discipline. We just need to apply some strategies according to the needs of subjects nature of the trade-offs.

\section{G. Course content is different, the strategy chosen are also different}

Even if the same subjects, different courses have to choose different strategies. Such as mathematics, the goal of each unit is different; every strategy has different requirements for students, in which intelligence culture is different. If we use the same strategy, you can not achieve learning objectives.

In addition, we should care about that strategy provided in this paper is not complete. In the process of designing learning environment, teachers can adjust their own theory of multiple intelligences strategies. Although the strategy selection can be varied, but in the environmental design process, we must provide students with as much as possible to learn through multiple intelligences to the environment, so that students can use curriculum time to develop their multiple intelligence, but they also could enhance the learning effectiveness.

\section{References}

[1]FENG Yi-dong. The Network Learning Resource Design Based on Multiple-intelligence Theory. Journal of Hainan Normal University(Natural Science),2006 (12) : 314 (in Chinese)

[2]David Lazear.The Art of Teaching Multiple Intelligences.Beijing:China Light Industry Press,2004.201 (in Chinese)

[3]Linda Campbell. Multiple Intelligences Teaching and Learning Strategies. Beijing: China Light Industry Press ,2004.125(in Chines) 